\title{
Pelatihan, Pembinaan dan Pendampingan Kader Ibu Hamil dalam Melakukan Deteksi Dini Risiko Tinggi Kehamilan di Kelurahan Mojolangu Kota Malang
}

\author{
Training, Development and Assistance of Pregnant Women Cadres in Carrying Out Early \\ Detection of High Risk Pregnancy at Mojolangu Village, Malang City
}

\author{
Ervin Rufaindah ${ }^{1^{*}}$ \\ ${ }^{1}$ STIKES Widyagama Husada \\ *ervinrufaindah@yahoo.com
}

\begin{abstract}
ABSTRAK
Angka kematian ibu (AKI) merupakan salah satu indikator untuk melihat derajat kesehatan perempuan. Penyebab utama kematian ibu yaitu hipertensi dalam kehamilan dan perdarahan post partum. Penyebab ini dapat diminimalisir apabila kualitas Antenatal Care dilaksanakan dengan baik. Beberapa keadaan yang dapat menyebabkan kondisi ibu hamil tidak sehat antara lain adalah penanganan komplikasi, anemia, ibu hamil yang menderita diabetes, hipertensi, malaria, dan empat terlalu. Pengenalan kemungkinan terjadinya tanda bahaya kehamilan harus secara dini dan ditangani dengan benar oleh kader kesehatan. Apabila kader kesehatan kurang mampu melakukan deteksi dini terhadap komplikasi kehamilan, maka akan terjadi komplikasi lanjut yang akan mengakibatkan kematian ibu dan bayi. Kader hendaknya lebih memahami penggunaan buku KIA. Buku KIA yang harus diisi yaitu penulisan skor deteksi dini, apabila skor ini tidak terisi dengan baik, kemungkinan ibu yang memiliki faktor resiko akan memiliki komplikasi pada masa persalinan dan nifasnya. Sehingga diperlukan pemahaman terkait dengan petunjuk teknis pengisian buku tersebut (Utami, 2010).Tujuan dalam pengabdian masyarakat ini adalah Melakukan pelatihan pada kader, selanjutnya akan dilakukan pembinaan dan pendampingan pada kader saat melakukan deteksi dini kehamilan resiko tinggi pada ibu hamil di Kelurahan Mojolangu. Metode yang digunakan adalah Dilakukan pelatihan tentang kehamilan resiko tinggi, cara Pengisian Kartu Skor Poedji Rohjati (KSPR), Buku KIA. Pada akhir pelatihan akan dilakukan evaluasi terhadap proses pelatihan serta keberhasilan pelatihan. Tahap ketiga adalah dilakukan pendampingan terhadap kader ibu hamil oleh tim pengabdi dengan melakukan kunjungan rumah ibu hamil untuk melakukan deteksi dini resiko tinggi kehamilan dengan cara mengisi KSPR.Hasil yang didapatkan adalah Telah dilakukan Pelatihan bagi kader ibu hamil tentang cara deteksi dini resiko tinggi kehamilan dengan menggunakan KSPR (Kartu Skor Poedji Rohjati). Pendampingan ibu hamil dengan kunjungan rumah oleh kader sudah dilakukan. Pemberian edukasi tentang kehamilan oleh kader untuk ibu hamil dan keluarga. Tersedianya sarana dan prasarana yang digunakan dalam pendampingan ibu hamil oleh kader yaitu modul.
\end{abstract}

Kata kunci — Kader, Deteksi Dini, Kehamilan Resiko Tinggi

\begin{abstract}
Maternal mortality rate (MMR) is one indicator to see the health status of women. The main causes of maternal death are hypertension in pregnancy and postpartum hemorrhage. This cause can be minimized if the quality of Antenatal Care is implemented properly. Some conditions that can cause unhealthy conditions for pregnant women include handling complications, anemia, pregnant women suffering from diabetes, hypertension, malaria, and four too). Recognizing the possibility of pregnancy danger signs must be early and properly handled by health cadres. If health cadres are not able to carry out early detection of pregnancy complications, further complications will occur which will result in maternal and infant mortality). Cadres should better understand the use of the MCH handbook. The MCH handbook that must be filled in is writing an early detection score, if this score is not filled out properly, it is likely that mothers who have risk factors will have complications during childbirth and postpartum. So that an understanding is needed related to the technical instructions for filling out the book (Utami, 2010). The purpose of this community service is to conduct training for cadres, then coaching and mentoring will be carried out on cadres when conducting early detection of high risk pregnancies in pregnant women in Mojolangu Village The methods used are training on high-risk pregnancy, how to fill in the Poedji Rohjati Score Card (KSPR), MCH Handbook. At the end of the training, an evaluation of the training process and the success of the training will be carried out. The third stage is mentoring for pregnant women cadres by a service team by conducting home visits for pregnant women to carry out early detection of high-risk pregnancies by filling out the KSPR. KSPR (Poedji Rohjati Score Card). Assistance for pregnant women with home visits by cadres has been carried out. Providing education about pregnancy by cadres for pregnant women and their families. The availability of facilities and infrastructure used in assisting pregnant women by cadres, namely modules.
\end{abstract}

Keywords - Cadres, Early Detection, High Risk Pregnancy 


\section{Pendahuluan}

Organisasi Kesehatan Dunia (WHO) memperkirakan di seluruh dunia lebih dari 858 ribu ibu meninggal tiap tahun saat hamil atau bersalin. Angka kematian ibu (AKI) merupakan salah satu indikator untuk melihat derajat kesehatan perempuan. AKI dapat menggambarkan tingkat kesadaran perilaku hidup sehat, status gizi dan kesehatan ibu, kondisi kesehatan lingkungan, tingkat pelayanan kesehatan terutama untuk ibu hamil, pelayanan kesehatan waktu ibu melahirkan dan masa nifas. AKI juga merupakan salah satu target yang telah ditentukan dalam tujuan pembangunan milenium ke-5 yaitu meningkatkan kesehatan ibu dimana target yang akan dicapai sampai tahun 2015 adalah mengurangi sampai $3 / 4$ risiko jumlah kematian ibu. Rendahnya kesadaran masyarakat tentang kesehatan ibu hamil menjadi faktor penentu angka kematian (Kemenkes, 2015 [3]).

AKI di Jawa Timur tahun 2012 sebesar 97,43 per 100.000 kelahiran hidup dan tahun 2013 sebesar 97,39 per 100.000 kelahiran hidup. Terjadi penurunan AKI pada kedua tahun tersebut akan tetapi tidak signifikan. Ada beberapa faktor yang bisa menyebabkan kematian ibu. Misalnya dari sisi petugas kesehatan terkait dengan ketrampilan dan kompetensi pelayanan kesehatan. Namun ada pula dari sisi masyarakat yang menyangkut masalah pendanaan, sosial budaya, atau lainnya.

Penyebab utama kematian ibu yaitu hipertensi dalam kehamilan dan perdarahan post partum. Penyebab ini dapat diminimalkan apabila kualitas Antenatal Care dilaksanakan dengan baik. Beberapa keadaan yang dapat menyebabkan kondisi ibu hamil tidak sehat antara lain adalah penanganan komplikasi, anemia, ibu hamil yang menderita diabetes, hipertensi, malaria, dan empat terlalu (terlalu muda $<20$ tahun, terlalu tua $>35$ tahun, terlalu dekat jaraknya 2 tahun dan terlalu banyak anaknya $>3$ tahun). Sebanyak 54,2 per 1000 perempuan di bawah usia 20 tahun telah melahirkan, sementara perempuan yang melahirkan usia di atas 40 tahun sebanyak 207 per 1000 kelahiran hidup. Hal ini diperkuat oleh data yang menunjukkan masih adanya umur perkawinan pertama pada usia yang amat muda $(<20$ tahun) sebanyak $46,7 \%$ dari semua perempuan yang telah kawin (Kemenkes RI, 2015[3]).

Dalam rangka upaya penurunan AKI dan AKB peran pemerintah sangat berpengaruh dalam penyediaan fasilitas pelayanan kesehatan yang berkualitas serta penyediaan tenaga kesehatan yang terampil di fasilitas kesehatan. Hal ini berpengaruh akan risiko-risiko dan komplikasi yang mungkin muncul menyertai persalinan jika persalinan dilakukan pada fasilitas non faskes/di rumah, keterlambatan dalam perujukan akan terjadi bila akses tempat tinggal pasien jauh dari sarana kesehatan. Untuk itu, perlu adanya integrasi program Making Pregnancy Safer (MPS) dengan program Gerakan Sayang Ibu (GSI) yang lebih memfokuskan pada pemberdayaan masyarakat harus segera dilakukan agar percepatan penurunan AKI dan AKB dapat segera terwujud (Fathoni, Rumintang dan Hanafi 2012[1]).

Kader merupakan pembawa misi pembangunan kesehatan ditingkat paling bawah. Kader ini adalah kepanjangan tangan dari Puskesmas atau Dinas Kesehatan kepada masyarakat di wilayah kerjanya. Seorang kader kesehatan merupakan tenaga sukarelawan yang berasal dari masyarakat yang peduli terhadap kesehatan warga sekitarnya. Sampai saat ini kader kesehatan terkadang menjadi sumber rujukan bagi penanganan berbagai masalah kesehatan. Proses pendampingan memang dilakukan oleh bidan desa, namun demikian dalam menggerakkan masyarakat tidak terlepas dari peran kader sebagai orang yang membawa misi kesehatan serta terdekat dengan masyarakat. Kader kesehatan dikatakan berhasil dalam memfasilitasi proses pemberdayaan apabila diwujudkan melalui peningkatan partisipasi aktif masyarakat. Oleh karena kader kesehatan itu sebagai fasilitator harus terampil mengintegrasikan tiga hal penting yakni optimalisasi fasilitasi, waktu yang disediakan, dan optimalisasi partisipasi masyarakat.

Hambatan yang dialami para kader dalam melaksanakan kegiatan pembangunan kesehatan adalah sebagian besar kader tingkat pendidikan yang masih kurang dan belum mendapatkan pelatihan terhadap tugas-tugas sebagai kader Posyandu secara maksimal (Tse, Suprojo dan Adiwidjaja, 2017) [5]. Pengetahuan dan keterampilan kader bukan hanya dapat 
meningkat tapi juga dapat menurun. Hal ini dapat terjadi karena kader kurang aktif sehingga lupa tentang hal-hal yang telah dipelajari sehingga pengetahuannya menurun. Tingginya nilai pengetahuan dan keterampilan kader dipengaruhi oleh pendidikan formal, kursus kader, frekuensi mengikuti pembinaan, keaktifan kader di Posyandu dan lamanya menjadi kader. Oleh karena itu perlu dilakukan penyegaran, yang dimaksudkan untuk memelihara dan menambah kemampuan kader tersebut (Hamariyana, Syamsianah dan Winaryati, 2013 [2] ).

Peran dari kader posyandu terdiri dari 3 peran utama yakni pelaksana, pengelola dan pengguna. Kader hendaknya lebih memahami penggunaan buku KIA, karena di dalam buku KIA terdapat evaluasi kegiatan dan pelayanan yang telah diberikan. Bagian dalam buku KIA yang harus diisi yaitu penulisan skor deteksi dini, apabila skor ini tidak terisi dengan baik, kemungkinan ibu yang memiliki faktor risiko akan memiliki komplikasi pada masa persalinan dan nifasnya. Sehingga diperlukan pemahaman terkait dengan petunjuk teknis pengisian buku tersebut (Utami, 2010 [4] ).

Pengenalan kemungkinan terjadinya tanda bahaya kehamilan harus secara dini dan ditangani dengan benar oleh kader kesehatan. Apabila kader kesehatan kurang mampu melakukan deteksi dini terhadap komplikasi kehamilan, maka akan terjadi komplikasi lanjut yang akan mengakibatkan kematian ibu dan bayi. Kematian tersebut merupakan dampak komplikasi kehamilan utama yaitu perdarahan, hipertensi, infeksi dan abortus. Banyak kematian neonatal merupakan akibat langsung penatalaksanaan kehamilan dan kelahiran yang buruk (Rochjati, 2003 dalam Palupi 2013 [4]).

Saat ini, jumlah kader pendamping ibu hamil mencapai 740 orang, yakni: Ngawi sebanyak 102 orang kader, Sampang 101 orang kader, Pamekasan 102 orang kader, Trenggalek 53 orang kader, Bondowoso 88 orang kader, Situbondo 76 orang kader, Jember 115 orang kader dan Kabupaten Kediri 103 orang kader. Program tersebut sebagai upaya menurunkan angka kesakitan dan kematian ibu di saat hamil dan melahirkan melalui pengenalan pada ibu hamil tentang deteksi dini ibu hamil dengan risiko tinggi kehamilan.
Berdasarkan studi awal di Kelurahan Mojolangu ditemukan hasil bahwa jumlah kader sekitar 50 orang, kader kesehatan telah mengikuti pelatihan tetapi dalam melakukan deteksi pada ibu hamil risiko tinggi belum dapat melakukan dengan baik atau belum terlaksana dengan optimal. Oleh karena itu diperlukan pelatihan pada kader dimana selanjutnya akan dilakukan pembinaan dan pendampingan pada kader saat melakukan deteksi dini kehamilan risiko tinggi pada ibu hamil di Kelurahan Mojolangu. Melalui berbagai upaya tersebut diharapkan Posyandu di Kelurahan Mojolangu dapat memberikan layanan maksimal bagi ibu hamil dan menjadi Posyandu percontohan bagi Puskesmas yang lain di Kota Malang. Secara keseluruhan diharapkan Kelurahan Mojolangu menjadi lingkungan yang siaga bagi proses kehamilan setiap ibu.

\section{Target dan Luaran}

Luaran dari program ini adalah :

a. Program pendampingan ibu hamil oleh kader semakin optimal

b. Kegiatan rutin selama pendampingan ibu hamil dapat tercatat dan terlaporkan dengan baik sehingga ibu hamil dapat terdeteksi secara dini

c. Adanya upaya preventif dan promotif yang lebih optimal dalam rangka meningkatkan kesehatan ibu dan anak.

d. Adanya kerja sama antara STIKES Widyagama dengan Kelurahan Mojolangu dalam meningkatkan derajat kesehatan ibu dan anak.

e. Tersedianya modul untuk pendampingan ibu hamil.

f. Artikel ilmiah yang terpublikasi dalam bentuk Jurnal atau Prosiding

\section{Metodologi}

\subsection{Tahapan Kegiatan}

Berdasarkan solusi yang ditawarkan dan luaran yang dihasilkan, dibuat rencana kegiatan yang meliputi:

a. Tahap Pertama: Koordinasi dengan Bidan Kelurahan Mojolangu untuk menyepakati jadwal pelatihan bersama dengan kader ibu hamil. 
b. Tahap kedua, dilakukan pelatihan tentang :

- Kehamilan risiko tinggi

- Cara Pengisian Kartu Skor Poedji Rohjati (KSPR)

- Buku KIA

Sebelum dilakukan pelatihan, tahap pertama adalah pemberian pretest dengan menggunakan kuesioner untuk mengetahui pengetahuan Kader tentang kehamilan risiko tinggi dan Kartu Skor Poedji Rohjati (KSPR). Setelah pretest, dilanjutkan dengan pemberian materi tentang kehamilan risiko tinggi, Cara Pengisian Kartu Skor Poedji Rohjati (KSPR) serta buku KIA. Kemudian dilanjutkan dengan demonstrasi dan latihan Cara Pengisian Kartu Skor Poedji Rohjati (KSPR) oleh kader dengan pembagian kasus oleh pemateri. Sesi terakhir dilakukan post test untuk mengetahui pengetahuan kader setelah diberikan materi dan pelatihan. Kemudian Kader dibekali Modul tentang kehamilan risiko tinggi dan Kartu Skor Poedji Rohjati (KSPR), serta contoh buku kendali kader saat mendampingi ibu hamil. Pelatihan dilakukan selama 1 hari.

c. Pada akhir pelatihan akan dilakukan evaluasi terhadap proses pelatihan serta keberhasilan pelatihan.

d. Tahap ketiga adalah dilakukan pendampingan terhadap kader ibu hamil oleh tim pelatih selama 1-2 hari dengan melakukan kunjungan rumah ibu hamil untuk melakukan deteksi dini risiko tinggi kehamilan dengan cara mengisi KSPR.

\subsection{Pengadaan Media Sarana Dan Prasarana}

Sarana dan prasarana yang digunakan dalam program pengabdian masyarakat ini adalah media pelatihan dan pendampingan ibu hamil yaitu modul materi kehamilan risiko tinggi, buku KIA, buku kendali kunjungan kader dengan ibu hamil, laptop, LCD, alat tulis dan map plastik.

\subsection{Proses Evaluasi Pelaksanaan Dan Keberlanjutan Program}

Program monitoring dan evaluasi dalam kegiatan pengabdian masyarakat ini dilakukan untuk mengetahui kemajuan kemampuan kader dalam melakukan deteksi dini risiko tinggi kehamilan serta untuk mengetahui adanya kesulitan atau hambatan dalam kegiatan ini. Evaluasi dilakukan untuk melihat kemampuan kader sebagai pendamping ibu hamil meliputi kemampuan komunikasi, kedisiplinan melakukan kunjungan rumah serta kemampuan mengisi KSPR guna deteksi dini risiko tinggi kehamilan.

\section{Pembahasan}

\subsection{Kegiatan Pelatihan Deteksi Dini} Kehamilan Risiko Tinggi

Kegiatan pelatihan deteksi dini kehamilan risiko tinggi terhadap kader ibu hamil ini dilakukan melalui beberapa tahapan utama yakni: persiapan, pelaksanaan dan evaluasi. Tim pengusul bersama mitra saling berkoordinasi serta memiliki peran dan fungsi masing-masing dalam setiap tahap kegiatan. Berikut ini merupakan hasil kegiatan yang telah dilakukan tim pengusul bersama mitra dalam setiap tahapnya :

\subsection{Tahap Persiapan}

Proses persiapan dilakukan sejak bulan Juni 2019 melalui koordinasi antara tim pengusul bersama mitra yaitu bidan. Pada tahap ini ketua tim pengusul membuat surat tugas serta melakukan koordinasi internal secara intensif. Tim pengabdi terdiri atas 1 dosen dan 2 mahasiswi Program Studi DIII Kebidanan.

\subsection{Tahap Pelaksanaan}

Pelatihan yang dilakukan terhadap kader ini sebagai upaya untuk meningkatkan kesehatan ibu hamil dan janinnya. Acara Pelatihan Kader Ibu Hamil dihadiri oleh tim pengabdi yang terdiri atas 1 dosen dan 2 mahasiswa. Total jumlah target peserta kegiatan adalah 36 peserta yang dihadiri oleh 34 kader ibu hamil, bidan wilayah, dan ibu lurah. Peserta yang telah melakukan registrasi akan mendapatkan kit kegiatan. Pada sesi pertama acara dibuka oleh MC kemudian sambutan oleh ibu lurah, bidan wilayah dan dosen yang melakukan pengabdian masyarakat. Kemudian dosen yang melakukan pengabdian masyarakat menjelaskan gambaran 
pelatihan, agenda acara selama pelatihan yaitu dimulai dari pembukaan kemudian sambutansambutan. Para kader juga dipersilahkan menyampaikan harapan serta kekhawatiran/ masalah selama pelatihan. Acara berikutnya Fasilitator dan peserta saling memperkenalkan diri, untuk memulai suatu hubungan yang baik selama pelatihan dan proses pengabdian masyarakat ini.

Setelah itu diadakan pretest untuk melihat pengetahuan awal kader tentang deteksi dini kehamilan risiko tinggi dengan menggunakan kuesioner mengenai KSPR. Kuesioner berisi tentang persetujuan responden, karakteristik responden serta 20 soal multiple choice tentang Kartu Skor Poedji Rohjati (KSPR). Saat mengisi kuesioner, kader sangat antusias karena untuk melihat pengetahuan mereka sebelum diberikan pelatihan.
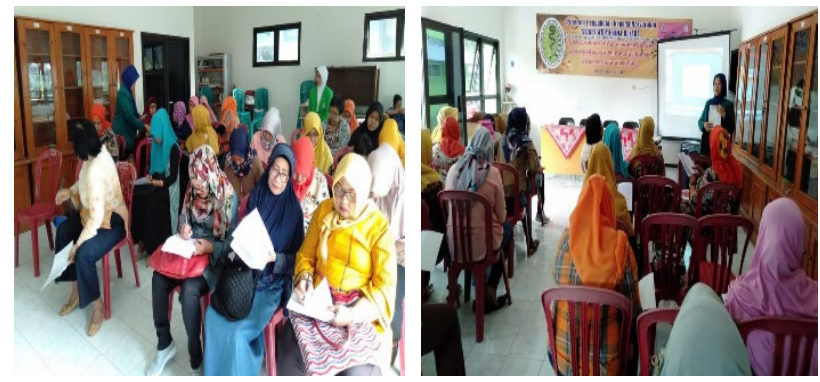

Gambar 1. Pretest dan Pemberian Materi Oleh Dosen STIKES Widyagama dan Bidan Wilayah

Acara berikutnya yaitu pemberian materi. Sebelum materi diberikan, para kader diberikan modul terlebih dahulu. Materi yang diberikan adalah tentang definisi deteksi dini (skrining), fungsi KSPR, klasifikasi kelompok faktor risiko, diagram skrining, pedoman penyuluhan menuju persalinan aman, cara mengisi KSPR yang disampaikan oleh Dosen STIKES Widyagama Husada. Setelah itu pemberian materi oleh Bidan Wilayah tentang buku kendali kader selama mendampingi ibu hamil. Tujuan pemberian materi ini adalah sebagai pengantar dan peningkatan pengetahuan pentingnya deteksi dini kehamilan risiko tinggi serta tugas dan peran tanggung jawab oleh Kader ibu hamil. Dalam pemberian materi, peserta yang mayoritas dihadiri oleh Kader ibu hamil sangat antusias dan aktif bertanya seputar kehamilan dan cara deteksi dini menggunakan KSPR.
Untuk memantapkan kemampuan kader dalam mengisi KSPR, setelah pemberian materi, kader diberikan soal latihan kasus secara individu, kemudian kader mengisi KSPR sesuai kasus tersebut. Kader sangat antusias dalam mengisi KSPR. Namun ada beberapa kesulitan saat mengisi seperti belum tepatnya isian dalam kolom trimester kehamilan, mengisi skor masuk ke dalam kelompok risiko. Nilai rata-rata pengisian KSPR oleh kader sebagai bentuk latihan ini adalah 80 .
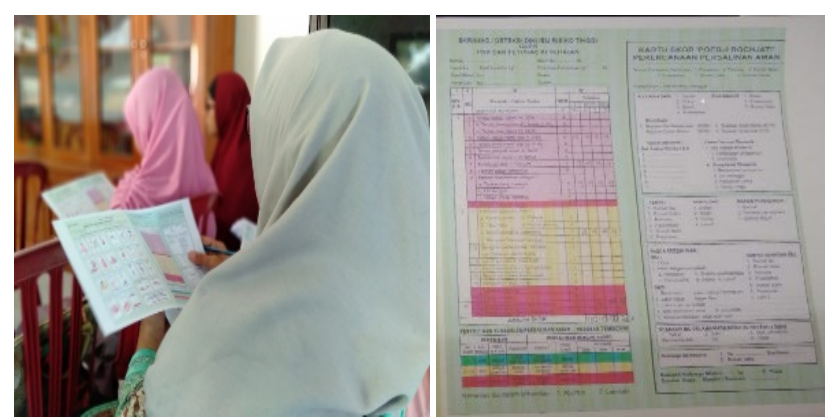

Gambar 2. Kader Latihan Mengisi KSPR

Acara berikutnya yaitu dilakukan post test dengan menggunakan kuesioner yang sama saat pretest untuk mengukur pengetahuan kader ibu hamil dalam melakukan deteksi dini kehamilan menggunakan KSPR setelah diberikan materi dan latihan pengisian KSPR. Setelah dilakukan analisa, ada kenaikan nilai rata-rata (mean) pengetahuan ibu-ibu kader sebelum dan sesudah pelatihan. Nilai mean sebelum pelatihan adalah 75,00 sedangkan nilai mean sesudah pelatihan adalah 84,23 , terjadi peningkatan nilai mean yaitu 9,23 .

Tabel 1. Peningkatan pengetahuan sebelum dan setelah penyuluhan

\begin{tabular}{lll}
\hline Pengetahuan & Mean & Beda Mean \\
\hline Sebelum & 75,00 & \\
Sesudah & 84,23 & 9,23 \\
\hline
\end{tabular}

Di akhir kegiatan pelatihan, dilakukan evaluasi terhadap pelatihan yang telah dilakukan yaitu berupa pengulangan kembali dan menyimpulkan secara singkat materi yang telah didapat dengan cara setiap kader menyampaikan persepsi terhadap materi yang telah mereka pahami. Beberapa demonstrasi mengisi KSPR juga dilakukan kembali agar kader mereview dan 
mengingat langkah-langkah dalam mengisi KSPR.

Kunjungan rumah dilakukan sesuai jadwal yang sudah disepakati. Kunjungan rumah pada ibu hamil dilakukan oleh tim pengabdi dan kader. Hal ini dilakukan sebagai bentuk pendampingan oleh tim pengabdi kepada kader. Selama kunjungan rumah, kader mampu mengisi lembar KSPR dengan baik. Artinya, meskipun terjeda waktu antara pelatihan dan kunjungan rumah, kemampuan kader tetap baik dalam mengisi KSPR. Hal ini dikarenakan Kader sering mempraktikkan pengisian KSPR saat mendampingi ibu hamil di wilayahnya. Sehingga dapat disimpulkan dengan pelatihan, pembinaan dan pendampingan kader oleh bidan, dapat meningkatkan pengetahuan dan ketrampilan kader dalam mengisi KSPR.
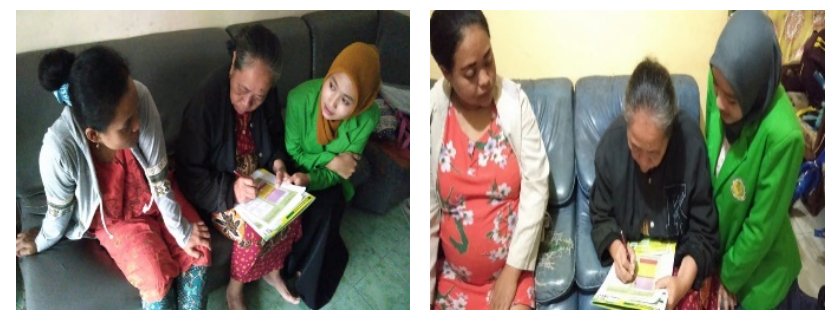

Gambar 3. Kunjungan Rumah Ibu Hamil Oleh Kader dan Tim Pengabdi

\section{Kesimpulan}

\subsection{Simpulan}

a. Pelatihan bagi kader ibu hamil tentang cara deteksi dini risiko tinggi kehamilan dengan menggunakan KSPR (Kartu Skor Poedji Rohjati).

b. Pendampingan ibu hamil dengan kunjungan rumah oleh kader.

c. Pemberian edukasi tentang kehamilan oleh kader untuk ibu hamil dan keluarga.

d. Tersedianya sarana dan prasarana yang digunakan dalam pendampingan ibu hamil oleh kader yaitu modul.

\subsection{Saran}

Kader pendamping ibu hamil diharapkan dapat melakukan tugasnya sebagai pendamping ibu hamil dengan baik dan terjadwal serta dapat melaporkan hasil pendampingan secara rutin kepada bidan wilayah.

\section{Daftar Pustaka}

[1] Fathoni, A., Rumintang, BI., Hanafi, F. 2012. Peran kader dalam deteksi dini kasus Risiko Tinggi Ibu Hamil dan Neonatus. Jurnal Kesehatan Prima, 6(2)

[2] Hamariyana., Syamsianah A., dan Winaryati E. 2013. Hubungan Pengetahuan dan Lama Kerja Dengan Ketrampilan Kader Dalam Menilai Kurva Pertumbuhan Balita di Posyandu Kelurahan Tegalsari Kecamatan Candisari Kota Semarang. Jurnal Gizi Universitas Muhammadiyah Semarang, 2(1)

[3] Kemenkes RI, 2015. Rencana Strategis Kementrian Kesehatan Tahun 2015-2019. Jakarta:Kemenkes RI diunduh dari http://www.depkes.go.id/resources/download/infopublik/Renstra-2015.pdf

[4] Palupi, FH., Fakhidah, LN dan Utami U. 2013. Tingkat pengetahuan kader kesehatan Tentang tanda bahaya kehamilan di desa Bolon kecamatan Colomadu. Jurnal KesMaDaSka, 4(1)

[5] Saraswati, DE dan Hariastuti, FP. 2017. Efektifitas Kartu Skor Poedji Rochjati (KSPR) untuk mendeteksi Resiko Tinggi pada ibu hamil di Puskesmas Ngumpakdalem Kabupaten Bojonegoro. Jurnal Ilmu Kesehatan MAKIA 5(1) 